\title{
Slovak thinking on audiovisual translation and the issue of the second-hand translation of Russian documentary films
}

\author{
Mikuláš M. \\ M.A., PhD student at the Department of Russian and East European Studies, Faculty of Arts, \\ Comenius University in Bratislava; e-mail: michal.mikulas@uniba.sk; ORCID: 0000-0002-6858-6058; \\ ACADEMIA: https://comeniusuniversity.academia.edu/Michal_Mikulas
}

(Bratislava)

\begin{abstract}
The paper, in its first part, outlines the Slovak research into audiovisual translation (AVT) from the 1950s up to the present, paying attention to the most important scholars as well as publications that helped to shape and establish the discipline within Slovak translation studies. It is based on the ongoing bibliographical research and the historical explanation mapping the development of AVT research in Slovakia by I. Tyšš - e.g. his publication Myslenie o audiovizuálnom preklade na Slovensku: 1952 - 2017 (Thinking on Audiovisual Translation in Slovakia: 1952 - 2017, 2018) - as well as on own findings covering the last two years. In more detail, the first part of the paper highlights that it was primarily thanks to a younger generation of translation studies scholars - especially E. Perez (née Janecová), L. Paulínyová (née Kozáková) and J. Želonka - that in 2012 the Slovak research into AVT finally became systematic. The second part of the paper is devoted to the phenomenon of the so-called second-hand translation of originally Russian audiovisual works that may be observed in Slovakia in recent years. The questionable nature of this phenomenon is stressed since the Russian language is not a language of limited diffusion and definitely not remote in relation to the Slovak cultural space. On the example of two documentary films - Под властью мусора (Held Captive by Rubbish, 2013) and Дух в движении (Spirit in Motion, 2015), the author discusses and analyses the problems that occur when translating originally Russian AV works into Slovak through the English language, i.e. the negative shifts resulting from mis-/overinterpretation of the source text, translation by omission, wrong order of dialogues, cultural specifics and incorrect transcription.
\end{abstract}

Key words: audiovisual translation, documentary films, voice-over, second-hand translation, translation problems, negative shifts.

Микулаш М. Словацкие исследования на тему аудиовизуального перевода и проблематика двухступенчатого перевода русских документальных фильмов. В первой части настоящей статьи представлен обзор словацких исследований, посвященных аудиовизуальному переводу (АВП) за период с 50-х гг. XX века по настоящее время. Внимание обращено прежде всего на характеристику наиболее значимых теоретиков, а также на труды, поспособствовавшие формированию и становлению данной дисциплины в словацком переводоведении. Статья опирается на непрерывно проводимые по данной теме исследования, а также на факты об историческом развитии АВП в Словакии, описанные напр. в публикации И. Тышша - Myslenie o audiovizuálnom preklade na Slovensku: 1952 - 2017 (Исследования на тему аудиовизуального перевода в Словакии: 1952 - 2017, 2018). Автор статьи демонстрирует и собственное восприятие сложившейся за последние годы ситуации. В первой части статьи акцентируется внимание на том, что в 2012 году словацкие исследования в области АВП стали более систематичными, прежде всего, за счет работы молодого поколения теоретиков - Э. Перез (в девичестве Янецовой), Л. Паулиньовой (в девичестве Козаковой) и Й. Желонки. Во второй части на материале русских аудиовизуальных произведений рассмотрен феномен т.н. двухступенчатого перевода, появление которого на словацких экранах стало более заметным в последнее время. Автор статьи делает упор на спорный характер настоящего феномена, поскольку русский язык не является малым языком, а с точки зрения словацкого культурного пространства не принадлежит и к числу отдаленных языков. На примере двух документальных фильмов «Под властью мусора» (Held Captive by Rubbish, 2013) и «Дух в движении» (Spirit in Motion, 2015) автор анализирует проблемы, которые могут возникнуть в процессе перевода русских аудиовизуальных произведений на словацкий язык через промежуточный английский язык, а именно рассматривает негативные искажения в переводе, наличие которых объясняется неправильной интерпретацией исходного текста, прием опущения при переводе, неверный порядок диалогов, культурную специфику и ошибочную транскрипцию.

Ключевые слова: аудиовизуальный перевод, документальный фильм, закадровый перевод, двухступенчатый перевод, проблемы перевода, негативные искажения в переводе. 
1. Introduction. In recent years, audiovisual translation (AVT), which is the object of my research, has become one of the most popular areas of interest within the translation studies research in Slovakia. It can be proven by the first Slovak conference on dubbing and subtitling (2016), first two monographs $(2016,2017)$ and a university textbook (2018) devoted to this subject matter and many papers and presentations, mainly by a younger generation of translation studies scholars (E. Perez, L. Paulínyová, J. Želonka, I. Tyšš, A. Zahorák and others), in which they deal with various aspects of AVT such as the role of a translator in the dubbing process, subtitling for the deaf and hard of hearing, audio description, didactics of AVT, localization of video games, etc.

The aim of this paper is to briefly characterize Slovak thinking on AVT in its historical development and then to focus on another topic that is being currently tackled within AVT research in Slovakia - the issue of the socalled second-hand translation. On the material of two documentary films - Под властью мусора (Held Captive by Rubbish) and Дух в движении (Spirit in Motion), our objective will be to identify and analyse the shifts that result from translating originally Russian AV works into Slovak through English. The relevance of the topic is undeniable because the Russian language is not a small language and definitely not remote in relation to the Slovak cultural space.

2. A brief overview of Slovak research into AVT. According to I. Tyšš and his findings [33, pp. 4-5], the beginnings of Slovak thinking on AVT go back to the 1950s (and may go even further to the 1940s, if not earlier). The first relevant paper on AVT that may be found in Tyššs's Bibliography [see 34, pp. 40-55] was written by a prominent film theorist, critic and translator P. Branko in 1952. In his paper entitled $K$ problematike filmových podtitulkov (On the Issue of Subtitles in Films) Branko not only stressed the fact that subtitles should be created from the film, not just from the dialogue list, but he also viewed the film as a synthetic art form with its own film language [see 4, p. 215]. Branko's approach, as I. Tyšš puts it, marks the beginning of a paradigm of thinking about film in the Slovak AVT which he proposes to call the film semiotic methodology [see 2018 a, p. 10]. The second and the last article from the 1950s raised a question whether to dub the films for children, since, as Branko had suggested earlier, subtitles were the most prevalent type of AVT because back then films could be watched only in cinemas.

As Tyššs bibliographical research shows [see 34, p. 19], the 1960s brought only a small number of relevant articles as well ( 5 in total), paying just partial attention to the aspect of AVT. However, with the gradual growth of TV culture in Czechoslovakia, by the early 1970s dubbing had come to replace subtitling as the most dominant form of AVT.

In the decade of the 1970s, 8 publications in total were devoted to AVT. The two most important papers that, according to I. Tyšš, "mark a watershed moment in the development of Slovak AVT research" [33, p. 11], were written by $\mathrm{K}$. Bednárová, back then a student of A. Popovič, nowadays one of the most significant translation studies scholars in Slovakia. In her first text $K$ problematike filmovej a televíznej adaptácie literárneho diela (On Film and TV Adaptations of Literary Texts, 1977), by employing a semiotic-communicative approach, she considers adaptation for the screen to be a case of intersemiotic translation. The second paper Dabing ako spôsob jazykovej komunikácie (Dubbing as a Means of Language Communication, 1979) basically confirms the fact that dubbing had already become the most preferred type of AVT in Slovakia. As Tyšš points out, by the end of the 1970s, Slovak scholars started adopting a linguistic semiotic approach to studying AVT which would later in time push out the older film semiotic methodology and the Slovak texts on AVT might be for the first time described as "theory" [see 33, pp. 11-12].

The number of publications devoted to AVT doubled in the following decade. Some of them were aimed at popularizing dubbing, some had more synthetizing character (e.g. Bednárová, 1983a; Bednárová, 1983b; Hochel, 1985). Bednárová's texts on translation of film dialogues and documentary film commentary translation appeared as entries in Popovičs Originál/ Preklad. Interpretačná terminológia (Original) Translation. Interpretation Terminology, 1983). Of importance was especially the entry on documentary film translation since it was the first Slovak text dealing with voice-over as one of the AVT modes. As to Hochel's text, it focused on various communicative aspects of translation for TV. According to Tyšš, one of the articles from the 1980s not referenced enough these days is V. Benedikovič's paper Funkcia titulku ako tlmočníka filmového dialógu (Functions of Subtitles as Intermediaries of Film Dialogues, 1987). It "discusses the complex functions of subtitles in their relation to film scenes and film dialogue, but not in their relation to the informational content or the utterance" and can be viewed as "a synthesis of the film semiotic approach to AVT" [33, pp. 12-13].

Despite dynamic social, political and cultural changes and the gradual development of AVT industry in Slovakia, the number of publications in the 1990s slightly decreased (12 overall). Besides several short articles addressing the state of dubbing and cinema after 1989 or the impact of new technologies on the AVT practice, arguably the most important text of the decade was written at its beginning. It was Hochel's chapter on dubbing which he included in his monograph Preklad ako komunikácia (Translation as Communication, 1990) and where he, among other things, presented the communication model of a dubbed film and reflected on the competences of a dubbing translator.

From Tyššs point of view, the first decade of the $21^{\text {st }}$ century can be "understood as an interstitial - an 
advertisement of sorts for what was to come" [33, p. 13]. Again, despite the dynamic nature of this period, not many notable texts on AVT were published. However, as the Bibliography suggests, the number of publications, in comparison to the $1990 \mathrm{~s}$, increased by 21 . One of the interesting tendencies that would later become vital and may be observed in this decade in relation to AVT research is practitioners' involvement in the academic discourse (Lesňák's paper on the dubbing practice from translator's perspective, Makarian's monograph on sound design in the dubbing process). Another question raised in the 2000s was how to call this new subdiscipline within translation studies since there had been no agreement on its name yet - e.g. translation of the text of film dialogues, translation of the text of documentary film commentary (Bednárová, 1983), translation in dubbing (Hochel, 1990), translation of "film texts" (Kusá, 2001), dubbing translation (Lesňák, 2004). Therefore, in 2008, E. Gromová, proposed a broad enough term "translation for the audiovisual media" that would a) emphasize translational and intersemiotic nature of the subdiscipline and b) allow translation studies to further expand, drawing on the scope of "audiovisual media" [see 33, p. 14].

In the current decade, AVT managed to establish and explain itself within the Slovak translation studies. The overall number of publications surpassed 100, relevant topics covered by scholars expanded and the research into AVT finally became systematic. The milestone year in the context of Slovak thinking on AVT was the year 2012 when the number of publications for the first time reached double digits per year (14). The best year so far, when considering the number of publications devoted to AVT, was the year 2014 with 26 publications [see 34, p. 16]. Such development of the research into AVT since 2012 has been possible mainly thanks to a younger generation of translation scholars - E. Perez (nee Janecová), L. Paulínyová (nee Kozáková), J. Želonka - and other young researchers have followed in their footsteps in the next years.

E. Perez, the leading figure of the Slovak AVT research, devoted her first publications in 2012 and 2013 to the state of AVT, its research and didactics in Slovakia - e.g. Preklad pre audiovizuálne médiá v kontexte slovenskej teórie, kritiky a didaktiky prekladu (Translation for the Audiovisual Media in the Context of Slovak Translation Theory, Criticism and Didactics) and Audiovisual Translation - Dubbing and Subtitling in Slovakia. Since 2013 she has focused in her research predominantly on the translation of subtitles and since 2015 more precisely on the issue of subtitling for the deaf and hard-of-hearing - e.g. Titulky pre nepočujúcich ako špecifický typ prekladu (Subtitles for the Deaf and Hard of Hearing as a Specific Type of Translation, 2015); Audiovizuálny preklad a nepočujúci divák: problematika titulkovania pre nepočujúcich (Audiovisual Translation and the Deaf and Hard of Hearing Audience: Subtitling for the Deaf and Hard of Hearing, 2016) or Titulky pre nepočujúcich: problematika orientácie v deji a postavách
(Subtitles for the Deaf and Hard of Hearing: Viewer Reception of the Plot and Characters, 2016). In 2017, she summarized her research on this topic and presented it internationally as a chapter The Power of Preconceptions: Exploring the Expressive Value of Subtitles for the Deaf and Hard of Hearing in the collective monograph Languaging Diversity Volume 3: Language(s) and Power. E. Perez also co-edited two collections of papers aimed at AVT Audiovizuálny preklad: výzvy a perspektívy (Audiovisual Translation: Challenges and Perspectives, 2014) with E. Gromová and Audiovizuálny preklad 2: za hranicami prekladu (Audiovisual Translation 2: Beyond the Borders of Translation, 2015) with L. Paulínyová. She initiated the series of workshops that served as a platform for academics and practitioners to discuss the issues of AVT practice (2012-2015) and organized the first Slovak conference on AVT - Audiovisual Translation: Dubbing and Subtitling in the Central European Context (2016) as well.

While, as we mentioned, E. Perez focuses in her research mainly on subtitling, L. Paulínyová concentrates primarily on dubbing translation and the role of a translator in the dubbing process. She was dealing with AVT already in her dissertation and during $\mathrm{PhD}$ studies published several notable papers on this subject - e.g. Súčasný stav dabingu na Slovensku (The Current State of Dubbing in Slovakia, 2013) or Špecifiká prekladu dokumentárnych filmov (Specifics of Documentary Films Translation, 2014). Perhaps the most favourable response out of her earlier publications was given to the paper Koncepcia audiovizuálneho prekladu (Concept of Audiovisual Translation, 2013) where she proposed a more straightforward name for the subdiscipline "audiovisual translation" - which would be more in line with the naming conventions outside Slovakia, but at the same time also rooted in the Slovak tradition [see 33, p. 14]. After successfully defending her dissertation, she continued to pay attention to AVT - e.g. Ako sa menípreklad pod rukami dabingového úpravcu (On How Translation Changes in the Hands of a Dialogue Writer, 2015); The Dubbing Process in Numbers: Who Changes Translation the Most?, 2016 or Práca dabingového prekladatel'a $Z$ pohladu dabingových hercov (Dubbing Translator's Work from the Viewpoint of Dubbing Actors, 2017). L. Paulínyová synthesized her findings in the monograph $Z$ papiera na obraz: proces tvorby audiovizuálneho prekladu (From the Paper to the Screen: The Audiovisual Translation Creation Process, 2017) where she included the theory of AVT into Popovič's table of translation disciplines and came up with her own classification of AVT [see 22, p. 26]. In 2018, she and E. Perez co-authored a chapter on AVT teaching in the collective monograph Didaktika prekladu a tlmočenia na Slovensku (Didactics of Translation and Interpreting in Slovakia).

In the last two years, research topics related to AVT in Slovakia have broadened even more. The already established as well as up-and-coming young scholars turn their attention, for example, to the sociological aspects and praxeology of AVT (E. Perez), bibliographical 
research and historiography of AVT (I. Tyšš), specifics of AVT for the child audience (A. Zahorák), subtitling and localization of video games (M. Koscelníková, M. Kabát), audio description (Z. Jánošíková) and the second-hand or relay translation in the context of AVT (M. Mikuláš). And it is indeed the issue of translating originally Russian AV works into Slovak through English that will be later dealt with in this paper.

2.1. Russian documentary films on Slovak TVs. As the results of our earlier research into Russian documentary films in Slovak translation after 1989 [see 18, pp. 62-64] show, the "turning" year which marked the return to the systematic selection of Russian documentaries for translation and broadcasting purposes was the year 2010. Since then, 23 documentaries in total have been translated into Slovak (the best years in relation to the number of translated and broadcasted documentary films were the years 2010, 2013 and 2015 with 5 documentaries). Except for one documentary series that was broadcasted on the private news channel TA3 in 2013, TV viewers could watch all of them on RTVS (Radio and Television of Slovakia), a public broadcasting organisation (until the 2011 merger just Slovak Television). The majority of broadcasted Russian documentary films were dealing with historical themes - e.g. 1812 (Napoleonic Wars in Russia), Тайны первой мировой войны (WWI Top Secrets) or Сталинградская битва (The Battle for Stalingrad). One interesting phenomenon that this research helped to reveal was that some of these documentaries were and/ or might have been translated into Slovak not directly from Russian, but through the English language.

2.2. Second-hand translation - why? A. Popovič understands the second-hand translation as "the translation mediated by another translation, i.e. translation when a translator does not speak the language of the source text and instead of a direct contact with the linguistically incomprehensible source text, he or she uses already translated text into a language he or she is capable of translating from" [31, p. 230, transl. M. M.]. He also stresses that it is typical for "small" and distant or remote languages [see 31, p. 230]. Despite the fact that this phenomenon cannot always be avoided as far as the documentary films translation is concerned (e.g. a documentary about indigenous peoples of Africa where they speak in their mother tongue), in this case it seems rather questionable since the Russian language is not a language of lesser diffusion and definitely not remote in relation to the Slovak cultural space.

In the following lines, we will aim our analysis at two bilingual dialogue lists of two originally Russian documentary films that were translated into Slovak through English (one of them partially). The first one is an investigative documentary about environmental problems our world is facing today - Под властью мусора (Held Captive by Rubbish, 2013), the second documentary -
Дух в движении (Spirit in Motion, 2015) - is the official documentary film of the 2014 Paralympic Winter Games in Sochi. It is important to mention that in the first documentary we encounter only two languages - Russian and English. On the other hand, the second documentary features altogether five languages - Russian, English, German, Portuguese and Chinese (all the athletes share their story in their mother tongue, however, Russian and English are represented the most and the dialogue list is also available in these two languages). In our analysis, we will, of course, focus solely on those parts of the second documentary that are in Russian and English not only in the script, but also in the video.

2.3. Analysis of selected examples. Just by quickly running our eyes over the two dialogue lists, we can immediately notice a relatively large number of negative shifts. Therefore, the objective of our analysis will be to comment on some selected examples from the Russian-English scripts and to point out the potential pitfalls a translator into Slovak may expect when he or she speaks only one of these languages. The first examples that we present result from translator's misor overinterpretation of the source text.

Table 1 - mis-/overinterpretation of the source text $[30$, pp. 8, 9]

\begin{tabular}{|l|l|}
\hline $\begin{array}{l}\text { Мы наивно предполагаем, что } \\
\text { мы сможем стать богами. }\end{array}$ & $\begin{array}{l}\text { In our naivety, we decided } \\
\text { we could be gods... }\end{array}$ \\
\hline$[\ldots]$ & {$[. .]$.} \\
\hline $\begin{array}{l}\text { To, что сопровождает } \\
\text { каждое достижение } \\
\text { цивилизации. }\end{array}$ & $\begin{array}{l}\text { Something which is } \\
\text { a consequence of every } \\
\text { achievement. }\end{array}$ \\
\hline Мусор. & The garbage. \\
\hline
\end{tabular}

As we can notice from the first example, a translator evidently overinterpreted the meaning of underlined Russian verbs, and thus made the sentences in English translation more definitive: 1. предполагать $\leftrightarrow$ to decide, 2. сопровождать $\leftrightarrow$ to be a consequence. In the first sentence, the translator even emphasized it by using the past tense. Since it does not correspond with the intent of the author of the source text and in order to avoid a possible negative shift in case of translating the documentary Под властью мусора (Held Captive by Rubbish) into Slovak through English, we would suggest more adequate solutions: e.g. 1. In our naivety, we suppose we could be gods. 2. Something that goes hand in hand with every achievement.

The same problem, however in this case in the opposite direction - i.e. in Russian translation of the script, may be observed also in the second documentary Дух в движении (Spirit in Motion): e.g. 1. Jason: I wasn't enjoying life, I didn't think I could be happy as an amputee, I didn't have any self-acceptance. I thought I was paying the price. $\leftrightarrow$ Джейсон: Я не радовался жизни, не думал, что можно быть счастливым инвалидом. Я не мог принять себя таким. Но если игра- 
ешь в игру, - ты получаешь свой приз! [7, p. 13] misinterpretation of the phrasal idiom to pay the price (дорого расплатиться за что). 2. Rico: I was thinking about him a lot. Has anybody reached out to him, has anybody tried to talk to the boy? He's growing up upset, maybe he's mad that he lost his father. $\leftrightarrow$ Рико: Я много думал о нём. Достучится ли кто-то до него? Попытается ли кто-то поговорить с этим мальчиком? Он растёт. Может, он грустит, может он сходит с ума без отца. [7, p. 24] - misinterpretation of the polysemous adjective mad (рассерженный).

Another common problem that a translator has to tackle is the so-called translation by omission. Since it is usually immediately obvious that something is wrong (unlike in the first example) and the text integrity principle is one of the basic translation rules, the translator must be ready to either consult a dictionary or ask for help one of his/her colleagues that speak the necessary language. Considering the given example from the documentary Под властью мусора (Held Captive by Rubbish), we can see that one piece of information about the person is completely lost in the English translation of the descriptive subtitle: главный научный сотрудник отдела ВИНИТИ $P A H \leftrightarrow \emptyset$. Except for holding doctor's degree in geography, Kim Losev in fact works as the leading researcher at the AllRussian Institute for Scientific and Technical Information of the Russian Academy of Sciences (also known under the acronym VINITI RAS or just VINITI).

Table 2 - translation by omission [30, p. 9]

\begin{tabular}{|l|l|}
\hline $\begin{array}{l}\text { Ким Лосев, доктор } \\
\text { географических наук, главный } \\
\text { научный сотрудник отдела }\end{array}$ & $\begin{array}{l}\text { Doctor of Geography } \\
\text { Kim Losev }\end{array}$ \\
ВИНИТИ РАН & \\
\hline
\end{tabular}

Sometimes it may lead not only to the omission of key information, but also to the stylistic weakening: e.g. Студент ГарвардаХью Мур публикует разоблачительную статью о вредности общей посуды. $\leftrightarrow$ A student of Harvard University Hugh Moore published an article about commonly used tableware. [30, p. 13] - 1. omission of the literary/bookish adjective разоблачительный (revealing or eye-opening), 2. omission of the noun вредность (harmful effects or harmfulness).

Since the narrated commentary (voice-over) requires that the utterance of a respondent in a documentary film (the so-called talking head) be shorter in translation in order to guarantee an impression of authenticity [see, 22 , p. 98], the order of dialogues in the script is very important. As the example from the documentary Дух в движении (Spirit in Motion) demonstrates, it is not always a standard and the translator should keep that in mind. Otherwise, such translation of the documentary film may arouse suspicion among TV viewers.

What every professional translator is definitely aware of is the issue of cultural specifics. However, there is no possibility to use footnotes or any other sort of explication within AVT due to time constraints and thus, finding the right solution can be sometimes very tricky. As the example below illustrates, the problem in this case was the Russian word этаж.

\section{Table 3 - order of dialogues [7, p. 14]}

\begin{tabular}{|c|c|}
\hline $\begin{array}{l}\text { Jason: I hope I could make it } \\
\text { to Sochi. I'm definitely easily } \\
\text { in the Top-5 in my country. }\end{array}$ & $\begin{array}{l}\text { Джейсон: Я вхожу в пятёрку } \\
\text { лучших горнолыжников } \\
\text { Австралии. }\end{array}$ \\
\hline $\begin{array}{l}\text { My skiing is not at Paralympic } \\
\text { level at this stage. }\end{array}$ & $\begin{array}{l}\text { И я очень надеялся } \\
\text { попасть на игры в Сочи, но } \\
\text { я пока не достиг уровня } \\
\text { Паралимпийских игр. }\end{array}$ \\
\hline
\end{tabular}

Table 4-cultural specifics [7, p. 25]

\begin{tabular}{|l|l|}
\hline Andrey: I was playing at a & Андрей: На стройке играли, \\
construction site, I had to run, & там надо было убегать, \\
hide. It was a sunny day and & прятаться. Был день \\
the light played a trick on me, & солнечный. Такая игра света \\
I ran behind a corner and it & и тени, забежал в закуток, \\
turned out to be an elevator & оказалось, что это шахта \\
shaft. And fell from the fourth & лифта. И упал с четвертого \\
floor. & этажа. \\
\hline
\end{tabular}

Since in the Russian cultural space the ground floor is called первый этаж, the expression четвертый этаж should not be translated as the fourth, but the third floor (in Slovak - tretie poschodie). Although there is a chance that the change of a numeral at the end of person's utterance may stir up some confusion (see the question of authenticity mentioned above), the translator into Slovak has an option to use the word podlažie instead of poschodie without risking any negative shift or confusing the viewer: четвертый этаж $\leftrightarrow$ third floor $\leftrightarrow$ štvrté podlažie.

The last potential pitfall we would like to mention is transcription. The Anglicist who translates originally Russian AV works, in our case documentary films, into Slovak through the English language needs to remember that he or she cannot stick to the Englishoriented transliteration system. Instead, the translator has to consult one of the codification publications of the Slovak language - Pravidlá slovenského pravopisu (The Rules of Slovak Orthography) - where the guidelines of practical transcription can be found. Below we present several examples from the analysed documentaries and offer also the transcription of proper nouns into Slovak.

Table 5 - transcription

\begin{tabular}{|l|l|l|}
\hline Екатеринбург & Ekaterinburg & Jekaterinburg \\
\hline Михаил Горбачев & Mikhail Gorbachev & Michail Gorbačov \\
\hline Оксана Слесаренко & Oksana Slesarenko & Oxana Slesarenková \\
\hline $\begin{array}{l}\text { Светлана } \\
\text { Пахомова }\end{array}$ & $\begin{array}{l}\text { Svetlana } \\
\text { Pakhomova }\end{array}$ & Svetlana Pachomovová \\
\hline $\begin{array}{l}\text { Александр } \\
\text { Шевченко }\end{array}$ & $\begin{array}{l}\text { Aleksandr } \\
\text { Shevchenko }\end{array}$ & Alexandr Ševčenko \\
\hline Дмитрий & Dmitry Artamonov & Dmitrij Artamonov \\
Артамонов & Mikhail Delyagin & Michail Del'agin \\
\hline Михаил Делягин & Andrei Shestakov & Andrej Šestakov \\
\hline Андрей Шестаков & \multicolumn{2}{|l}{} \\
\hline
\end{tabular}


3. Conclusion. Despite the fact that Slovak research into AVT finally became systematic only in the current decade, more precisely in 2012, it can be argued that in a relatively short time it pretty quickly managed to catch up with thinking on AVT outside from Slovakia. It was primarily thanks to a younger generation of translation scholars who in the last couple of years brought to the table a wide range of relevant research topics. One of the issues that is nowadays dealt with also in my research is the phenomenon of the so-called second-hand translation. According to my earlier findings, in recent years, several originally Russian AV works (not just documentaries, but even children's animated series) have been translated into Slovak through the English language. While the occurrence of this phenomenon remains unclear, since Russian is not a small language and definitely not remote in relation to the Slovak cultural space, as we have seen from the examples above, it may present various challenges not only to a translator, but also to the other creators of the Slovak version of an AV work. Those challenges and the potential negative shifts resulting from them will be later classified and studied in more detail in my dissertation - however, this time on the material of the documentary series Освободители (The Liberators).

\section{REFERENCES}

1. Bednárová, K. (1977). K problematike filmovej a televíznej adaptácie literárneho diela. Slavica Slovaca, 12(4), $383-387$.

2. Bednárová, K. (1979). Dabing ako spôsob jazykovej komunikácie. Panoráma, 5(2), 30-36.

3. Benedikovič, V. (1987). Funkcia titulku ako tlmočníka filmového dialógu. Slovenské divadlo, 35(3), 291-326.

4. Branko, P. (1952). K problematike filmových podtitulkov. Slovenská reč, 17(7-8), 214-233.

5. Cambridge Dictionary. English Dictionary. Cambridge University Press, 2019. Available at: https://dictionary.cambridge. org/dictionary/english/

6. Dukh v dvizhenii (Spirit in Motion). Directed by Yulia Byvsheva, Sofia Geveyler, Sofia Kucher. Production Center VGIK-Debut. Ostrov Studio, 2015. 73 min.

7. Dukh v dvizhenii (Spirit in Motion). Montazhnye listy. Production Center VGIK-Debut. Ostrov Studio, 2015.

8. Gromová, E. (2008). Preklad pre audiovizuálne médiá. In: Slovo - obraz - zvuk: Duchovný rozmer súčasnej kultúry. Nitra: Univerzita Konštantína Filozofa v Nitre, pp. 136-143.

9. Gromová, E., and Janecová [Perez], E. (eds.) (2014). Audiovizuálny preklad: výzvy a perspektívy. Nitra: Univerzita Konštantína Filozofa v Nitre.

10. Gromová, E., and Perez, E. (2013). Audiovisual Translation - Dubbing and Subtitling in Slovakia. World Literature Studies, 2013, 5(4), 61-71.

11. Hochel. B. (1990). Preklad ako komunikácia. Bratislava: Slovenský spisovatel'.

12. Janecová [Perez], E. (2012). Preklad pre audiovizuálne médiá v kontexte slovenskej teórie, kritiky a didaktiky prekladu. In: Prekladatel'ské listy 1. Bratislava: Univerzita Komenského, pp. 22-28.

13. Kozáková [Paulínyová], L. (2013). Koncepcia audiovizuálneho prekladu. In: Letná škola prekladu 12: Odkaz Antona Popoviča, zakladatel'a slovenskej prekladovej školy - pri príležitosti 80. výročia jeho narodenia. Bratislava: SSPUL, SSPOL, pp. 149-158.

14. Kozáková [Paulínyová], L. (2013). Súčasný stav dabingu na Slovensku. In: Tradícia a inovácia v translatologickom výskume IV. Nitra: Univerzita Konštantína Filozofa v Nitre, pp. 90-100.

15. Kozáková [Paulínyová], L. (2014). Špecifiká prekladu dokumentárnych filmov. In: Audiovizuálny preklad: výzvy a perspektívy. Nitra: Univerzita Konštantína Filozofa v Nitre, pp. 69-89.

16. Kusá, M. (2001). Umelecký preklad trochu inak, alebo, 0 preklade „filmových textov“ v dobe meniacich sa trhov: Úvahy o jednom pomedzí umeleckého prekladu. Slovak Review, 10(2), 157-162.

17. Lesňák, R. (2004). Špecifiká dabingového prekladu. In: Letná škola prekladu 2: Kvalita prekladu a prekladatel'ské kompetencie. Bratislava: AnaPress, pp. 128-131.

18. Mikuláš, M. (2017). Slovenské preklady ruských dokumentárnych filmov po roku 1989 a problematika prekladu z druhej ruky. In: Mladá rusistika - nové tendencie a trendy IV. Bratislava: Stimul, pp. 61-69.

19. Paulínyová, L. (2015). Ako sa mení preklad pod rukami dabingového úpravcu. In: Letná škola prekladu 14: Minulost’ a budúcnost' prekladu: Od Ludovíta Štúra po strojový preklad. Bratislava: SSPUL, SSPOL, pp. 136-149.

20. Paulínyová, L. (2016). The Dubbing Process in Numbers: Who Changes Translation the Most? In: Audiovisual Translation: Dubbing and Subtitling in the Central European Context. Nitra: Univerzita Konštantína Filozofa v Nitre, pp. 11-22.

21. Paulínyová, L. (2017). Práca dabingového prekladatela z pohladu dabingových hercov. In: Prekladatel'ské listy 6. Bratislava: Univerzita Komenského, pp. 95-112.

22. Paulínyová, L. (2017). Z papiera na obraz: proces tvorby audiovizuálneho prekladu. Bratislava: Univerzita Komenského.

23. Paulínyová, L., and Perez, E. (eds.) (2015). Audiovizuálny preklad 2: za hranicami prekladu. Nitra: Univerzita Konštantína Filozofa v Nitre.

24. Perez, E. (2015). Titulky pre nepočujúcich ako špecifický typ prekladu. In: Audiovizuálny preklad 2: za hranicami prekladu. Nitra: Univerzita Konštantína Filozofa v Nitre, pp. 35-48.

25. Perez, E. (2017). The Power of Preconceptions: Exploring the Expressive Value of Subtitles for the Deaf and Hard of Hearing. In: Languaging Diversity Volume 3: Language(s) and Power. Newcastle upon Tyne: Cambridge Scholars Publishing, pp. 188-204. 
26. Perez, E., and Gromová, E., and Zahorák, A., and Hodáková, S. (2016). Audiovizuálny preklad a nepočujúci divák: problematika titulkovania pre nepočujúcich. Nitra: Univerzita Konštantína Filozofa v Nitre.

27. Perez, E., and Paulínyová, L. (2018). Výučba audiovizuálneho prekladu na Slovensku. In: Didaktika prekladu a tlmočenia na Slovensku. Bratislava: Univerzita Komenského, pp. 178-201.

28. Perez, E., and Zahorák, A. (2016). Titulky pre nepočujúcich: problematika orientácie v deji a postavách. In: Slavica Iuvenum XVII. Mezinárodní setkání mladých slavistů. Ostrava: Ostravská univerzita, pp. 368-376.

29. Pod vlast'ju musora (Held Captive by Rubbish). Directed by Anastasia Popova. VGTRK. Edinaja medija gruppa, 2013. 49 $\min$.

30. Pod vlast'ju musora (Held Captive by Rubbish). Montazhnye listy. VGTRK. Edinaja medija gruppa, 2013.

31. Popovič, A. et al. (1983). Originál/Preklad. Interpretačná terminológia. Bratislava: Tatran.

32. Tolkovyj slovar' Ushakova. Slovari i entsiklopedii na Akademike. Akademik, 2000-2019. Available at: https://dic.academic. ru/contents.nsf/ushakov/

33. Tyšš, I. (2018). Audiovisual translation meets Slovak translation studies: a historian's take on a discipline in the making. Translatologia, 2(1), 2-22.

34. Tyšš, I. (2018). Myslenie o audiovizuálnom preklade na Slovensku: 1952 - 2017. Nitra: Univerzita Konštantína Filozofa v Nitre.

\section{СВЕДЕНИЯ ОБ АВТОРЕ}

Микулаш Михал - магистр, аспирант на кафедре русистики и восточноевропейских исследований философского факультета Университета им. Коменского в г. Братислава; e-mail: michal.mikulas@uniba.sk; ORCID: https://orcid.org/00000002-6858-6058; ACADEMIA: https://comeniusuniversity.academia.edu/Michal_Mikulas. 